\title{
BMT, PELUANG DAN TANTANGANNYA
}

Oleh:

Peni Nugraheni

Dosen Universitas Muhammadiyah Yogyakarta

ABSTRACT

Baitul Maal wat Tamzwill (BMT) is syariah micro financing (organization that has developed becoming more than 3000 units since it is declared in 1994. BMT have large contribution to develop economic condition by giving loan to mikro enterprise. $B M T$ has some strengthness if compared with other financing organizations, but there are also many weaknesses that must be solved. This article try to describe the prospect of $B M T$ by using SWOT analysis and give some solution alternatif to support the future of BMT.

Keyzoord: BMT, SWOT, solution

Pada awal dasawarsa 1990-an, tepatnya pada tahun 1992 suatu perkembangan baru telah terjadi dalam sistem perbankan di indonesia. Perkembangan tersebut adalah adanya pendirian sebuah perbankan yang berprinsip syariah dengan landasan operasi berbasis bagi hasil (profit sharing) yaitu Bank Muamalat Indonesia (BMI).

Pada dasarnya ada tiga tingkatan kelas bank syariah secara umum di Indonesia yaitu bank umum, bank perkreditan rakyat, dan lembaga keuangan pedesaan. BMI mewakili bentuk bank umum syariah yang mempunyai wilayah operasi yang luas meliputi seluruh wilayah Indonesia. BMl bisa mendirikan cabang-cabangnya di berbagai kota.

Bentuk kedua dari bank syariah diwakili oleh Bank Perkreditan Rakyat Syariah (BPRS) yang keberadaannya diatur dalam Undang-Undang Perbankan No.10 tahun 1998. Badan hukum bank ini adalah perseroan terbatas (PT) sehingga secara umum manajemen dikelola secara profesional sesuai dengan UU No.1 tahun 1995 tentang perseroan terbatas. Perkembangan jumlah PT. BPRS di Indonesia cukup baik yaitu terdapat 92 PT. BPRS (Republika 2005).

Bentuk ketiga dari bank syariah diwakili oleh Baitul Maal wat Tamwil(BMT). BMT mempunyai wilayah operasi yang lebih sempit dibanding dua lembaga keuangan syariah sebelumnya. Sebagian besar BMT mempunyai wilayah operasi di daerah pedesaan dan kawasan pinggiran perkotaan (sub-rural area). BMT merupakan sebuah fenomena yang tergolong baru di tengah-tengah masyarakat muslim Indonesia, sehingga eksistensi BMT belum diakui sepenuhnya. Padahal, sejak kemunculannya pertama kali sekitar tahun 1994 sampai saat ini tercatat ada lebih dari 3000 BMT di seluruh Indonesia (Republika, 2005). Jumlah ini tentunya akan berubah tergantung prospek yang dimiliki BMT. Oleh karena itu; sangatlah tepat apabila muncul sebuah pertanyaan, bagaimana prospek BMT mendatang?

Sebagai jawaban pertanyaan tersebut, maka tulisan ini bertujuan untuk 
Peni Nugraheni: BMT, Peluang dan Tantangannya

mencoba mengetahui prospek BMT mendatang dengan terlebih dahulu melakukan analisa SWOT (Strength, Weakness, Opportunity, and Threaten).

Pada bagian kedua tulisan ini akan membahas profil BMT secara umum. Bagian ketiga akan menganalisa kekuatan (strength), kelemahan (weakness), peluang (opportunity), dan ancaman (threaten) yang dimiliki BMT. Bagian keempat akan memberikan alternatif solusi terhadap kelemahan dan ancaman yang dihadapi BMT. Bagian kelima merupakan penutup dengan memberikan kesimpulan dan rekomendasi dari pembahasan ini.

\section{B. PROFIL BAITUL MAAL WAT TAMWIL}

\section{a.Sejarah}

BMT merupakan Balai-Usaha Mandiri Terpadu yang mempunyai konsep sebagai Baitul Maa/ wat Tamwil, yang berarti bahwa lembaga ini mempunyai dua inti pokok kegiatan. Pertama, kegiatan Baitul Maal meliputi penyaluran dana ZIS (Zakat, Infaq, dan Shadaqah). Kedua, kegiatan at tamwil yang meliputi kegiatan penerimaan tabungan dan penyaluran dana pembiayaan bagi masyarakat yang membutuhkan dana pinjaman (PINBUK, 1999).

Awal sejarah pendiriannya BMT merupakan sebuah lembaga keuangan alternatif. Inj terjadi karena UU No.7 tahun 1992 saat itu tentang perbankan hanya mengakui adanya dua lembaga keuangan bank yaitu bank umum dan Bank Perkreditan Rakyat (BPR). Bank umum mempunyai wilayah operasi yang cukup luas yaitu meliputi wilayah perkotaan dan sekitarnya. BPR mempunyai wilayah operasi yang lebih sempit yaitu kecamatan. Salah satu butir peraturan tersebut menyatakan tidak diperkenankan berdiri lebih dari satu BPR. Hal ini mempunyai tujuan untuk mengurangi persaingan yang tidak sehat dan juga untuk melindungi kepentingan BPR dalam menjaga likuiditas dana.

Namun hal tersebut justru menjadi tidak efektif karena BPR bisa memonopoli pasar. Hal ini akhirnya akan merugikan nasabah karena BPR merasa tidak perlu lagi menjaga kualitas pelayanannya. Disisi lain perkembangan dunia usaha menuntut adanya modal yang cukup dengan mekanisme pembiayaan yang mudah. Banyak pengusaha yang tidak dapat mengembangkan usahanya karena tidak mendapat pinjaman modal BPR dengan alasan legal formal dan faktor ketersediaan jaminan.

Sebagai langkah untuk mensiasati peraturan pemerintah tersebut, maka dibentuklah BMT sebagai salah satu solusi permasalahan tersebut. Hal ini memungkinkan karena pembentukan BMT tidak terikat dengan perafuran pemerintah seperti bank umum dan BPR. Usaha pertama dalam mewujudkan hal tersebut ternyata muncul di Bandung oleh Teknosa dan Ridho Gusti (Adnan, 2000). Lembaga keuangan yang pertama kali muncul adalah Baitut Tamwil. Bentuk ini hanya melayani kegiatan simpan pinjam saja. Namun usaha ini kandas di tengah jalan tanpa ada informasi yang jelas mengenai penyebab kegagalannya. Kemudian Baitul Maal wat Tamwil yang pertama kali berdiri adalah BMT Bina Insan Kamil. BMT ini didirikan oleh Yayasan Bina Insan Kamil pada tanggal 1 Juni 1992. 
Perkembangan selanjutnya adalah adanya Gerakan BMT yang dicanangkan oleh Presiden Soeharto pada tanggal 7 Desember $\{995$. Pada pasal 5 Peraturan Dasar BMT yang disusun oleh PINBUK (Pusat Inkubasi Bisnis Usaha Kecil) dijelaskan bahwa Gerakan BMT adalah segala üpaya kegiatan yang bertujuan mendirikan, menguatkan, mengembankan, dan memajukan BMT. Ini sebuah langkah maju yang diambil pemerintah RI dalam mendorong kekuatan ekonomi syariah.

\section{b. Status dan Legalitas Hukum}

Secara yuridis belum ada peraturan pemerintah yang secara jelas mengatur pembentukan BMT . Sebagai jembatan untuk mengatasi masalah tersebut, pemerintah mengatur dengan Peraturan Dasar BMT melalui bantuan PINBUK. Pasal 16 Peraturan Dasar BMT menjelaskan bahwa BMT dapat memperoleh status kelembagaan, sebagai berikut:

1. Kelompok Swadaya Masyarakat yang berada di bawah pengawasan PINBUK, berdasarkan naskah kerjasama YINBUK dengan PHBK-Bank Indonesia.

2. Berbadan Hukum Koperasi Jasa Keuangan Syariah:

(a) Koperasi Simpan Pinjam Syariah (KSP Syariah);

(b) Koperasi Serba Usaha Syariah (KSU Syariah) atau Koperasi UnitD e s a Syariah (KUD Syariah);

(c) Unit Usaha Otonom dari Koperasi seperti KUD, Kopontren, atau lainnya. Dalam prakteknya ada beberapa lembaga penggerak dan fasilitator BMT di Indonesia yaitu Muamalat Center Indonesia (MCI), INKOPSYAH BMT, Pusat Inkubasi Bisnis dan Usaha Kecil (PINBUK), BMT Center (Dompet Dhuafa), dan Baitul Maal Muamalat (BMM).

Ada juga BMT yang merasa telah memiliki kekuatan permodalan yang cukup kemudian mencoba meningkatkan statusnya menjadi PT.BPRS dengan memenuhi segala konsekuensi yang telah ditetapkan oleh pemerintah melalui Surat Keputusan Bank Indonesia N0. 32/36/KEP/DIR tanggal 12 Mei 1999 tentang BPR Syariah.

\section{c. Permodalan dan Kegiatan Usaha}

Permodalan BMT bisa diperoleh dari berbagai sumber; antara lain dari modal pendiri. Pendiri BMT sesuai pasal 13 Peraturan Dasar BMT sekurangkurangnya 20 orang. BMT didirikan dengan modal awal sebesar 50 juta rupiah atau lebih. Namun jika terdapat kesulitan dalam mengumpulkan modal awal, dapat dimulai dengan modal 20 juta rupiah.

Modal yang berasal dari pendiri nantinya membawa konsekuensi adanya SHU (Sisa Hasil Usaha) berupa bagi hasil sesuai kontribusi masing-masing. Selain itu, modal BMT bisa berasal dari BAZIS, Lembaga Pemodal Perangsang, maupun POKUSMA (Kelompok Usaha Sektor Riil). Namun tidak menutup kemungkinan modal tersebut diperoleh dari lembaga yang menaungi masingmasing BMT seperti PINBUK, Dompet Dhuafa Republika, dan lembaga lain yang berbentuk jamaah masjid atau koperasi.

Dari modal yang didapatkan tersebut BMT kemudian menjalankan usahanya dengan menawarkan berbagai macam produk yang meliputi:

a. Produk simpanan yaitu kegiatan BMT dalam menampung dana dari 
masyarakat untuk kemudian dikelola sebagai sumber pembiayaan bagi masyarakat yang membutuhkan. Para nasabah peminjam akan memperoleh bagi hasil dari keuntungan usaha yang dijalankan BMT. Salah sału produk simpanan yang lazim ditawarkan adalah simpanan mudharabah.

b. Produk pembiayaan yaitu kegiatan BMT dalam memberikan bantuan pinjaman pembiayaan bagi masyarakat yang membutuhkan dana baik untuk konsumsi rumah tangga atau menambah permodalan usaha. Dari kegiatan ini BMT mendapatkan bagi hasil yang diperoleh dari nasabah peminjam dengan prinsip win-win solution. Produk pembiayaan yang lazim ditawarkan adalah pinjaman mudharabah, musyarakah, al qordhul hasan, dan bai' bithaman ajil.

Disamping kegiatan tersebut sebagian besar BMT juga mengembangkan kegiatan usaha di sektor riil. Kegiatan ini bisa berbentuk usaha toko kelontong, kios kebutuhan bahan pokok, usaha jual beli kendaraan bermotor bekas, usaha peternakan, usaha agrobisnis, dan usaha lain yang menghasilkan keuntungan sesuai syariat Islam.

\section{ANALISA SWOT}

Setelah membahas profil BMT, pada bagian ini akan dianalisa kekuatan (strength), kelemahan (weakness), peluang (opportunity), dan ancaman (threaten) yang dimiliki BMT.

\section{A. KEKUATAN (STRENGTH)}

1. Pelayanan yang Baik

Standar kepuasan konsumen sebenarnya sangat relatif ukurannya khususnya untuk nasabah BMT. Hal ini terjadi karena tidak ada standar khusus pelayanan nasabah BMT. Kualitas pelayanan tergantung kepada perlakuan masing-masing BMT kepada nasabahnya. Berdasarkan penelitian yang pernah dilakukan PINBUK (1999) terungkap bahwa kepuasan konsumen tersebut dipengaruhi oleh dua faktor yaitu pertama, pelayanan BMT dengan mendatangi langsung konsumen baik untuk mengambil simpanan nasabah atau mengambil kewajiban dari nasabah peminjam. Dengan kata lain BMT bersikap proaktif dalam menjaring nasabah. Kedua, BMT memberikan prosedur yang mudah dan sederhana kepada para nasabah dan sistem bagi hasil yang menguntungkan.

a. Proaktif dalam menjaring nasabah

Salah satu ciri dari BMT adalah sikap aktif dari pengelola BMT dalam menjaring nasabah. Pengelola BMT menyadari bahwa kondisi pasar mereka sangatlah terbatas pada wilayah tertentu saja, sehingga kurang efektif jika mereka menggunakan sarana media massa atau elektronika dalam mempromosikan produk-produknya. Walaupun demikian tidak menutup kemungkinan BMT juga berpromosi melalui media-media tersebut sebagai salah satu upaya mengenalkan BMT secara lebih luas. Alat promosi yang biasanya digunakan antara lain pamflet, leaflet, booklet, dan iklan rádio.

Upaya menjaring nasabah yang paling efektif adalah adalah dengan sistem "jemput bola". Pengelola khususnya bagian pemasaran aktif mencari 
nasabah disekitar lokasi BMT. Pengelola datang langsung kepada caloncalon nasabah dan berusaha meyakinkan akan keuntungan menabung di BMT khususnya berkaitan dengan sistem bagi hasil yang ditawarkan. Mereka sadar bahwa nasabah merupakan VIP (very important person). Dengan konsep tersebut pengelola akan berusaha melayani nasabahnya sebaik mungkin.

Keunggulan lain yang dimiliki BMT adalah sikap kekeluargaan yang ditunjukkan oleh pengelola BMT. Mereka bahkan menganggap bahwa nasabah tersebut adalah keluarga mereka sendiri sehingga tidak jarang hubungan sehari-hari yang mereka jalin sangat fleksibel.

Kedekatan antara pihak BMT dan nasabah juga tercermin dengan diadakannya pengajian rutin bagi nasabah yang diselenggarakan oleh BMT. Hal ini merupakan wujud tanggung jawab BMT sebagaj sebuah institusi Islam dalam memupuk keimanan nasabahnya dan seluruh komponen BMT yang bersangkutan.

b. Prosedur yang praktis dan sistem bagi hasil yang menguntungkan Prosedur merupakan serangkaian tahap yang harus dilalui untuk mencapai sebuah target. Begitu pula yang ada pada lembaga-lembaga keuangan konvensional pada umumnya. Mereka menerapkan proseduryang panjang dengan berbagai macam syarat bagi calon nasabah yang ingin bergabung menjadi nasabah. Ini sangat dirasakan khususnya bagi nasabah peminjam

Kenyataan yang terjadi bahwa bank biasanya sangat selektif memilih kredit-kredit yang akan direalisasikan. Otomatis pengusaha golongan ekonomi menengah ke bawah tidak mungkin meminjam dana ke bank umum karena mereka kesulitan memenuhi prosedur yang berbelitbelit itu. Mereka cenderung beralih kepada lintah darat dengan alasan tidak ada prosedur yang rumit, walaupun mereka harus membayar bunga yang lebih tinggi. Peluang inilah yang ditangkap oleh BMT dengan memanfaatkan kondisi masyarakat golongan ekonomi menengah ke bawah yang menginginkan pinjaman modal untuk usahanya dengan prosedur yang praktis dan tidak ada bunga. Dengan prosedur yang sederhana, cepat dan mudah dipahami maka nasabah pun merasa sangat dibantu. Ada juga BMT yang hanya membutuhkan proses satu hari saja untuk mengajukan sebuah pinjaman. Kecepatan proses ini merupakan sebuah kekuatan bagi BMT karena hampir sebagian nasabah BMT adalah masyarakat golongan ekonomi menengah ke bawah dan memiliki tingkat pendidikan yang tidak begitu tinggi yang tidak mengerti masalah prosedur pengajuan permohonan pinjaman di bank umum. Prinsip mereka adalah uang bisa cepat dicairkan dan dia bisa cepat melunasi hutangnya. Nasabah terkadang justru tidak ingin memperlama pinjamannya karena mereka merasa bahwa hutang tersebut akan membelit mereka. Hal ini mengakibatkan perputaran dana BMT berjalan dengan baik.

Pembiayaan yang dilakukan dengan prinsip bagi hasil memberikan kemudahan bagi nasabah karena BMT menganut prinsip win-win solution. Ini berarti bahwa pada akad perjanjian dikemukakan bahwa keuntungan yang dibagikan kepada BMT akan semakin besar sesuai dengan 
peningkatan keuntungan dari nasabah itu juga.

Kalau mengamati pembiayaan mudharabah, maka pada sistem tersebut diterapkan sistem bagi hasil dan kerugian (profit and loss sharing) sesuai dengan kesepakatan bersama (Dumairy, 1999). Dengan hal ini pihak bank menanggung $100 \%$ dana pembiayaan yang diajukan/ diusulkan oleh pengusaha (debitur) dalam bentuk pengadaan barang modal. Jika terdapat keuntungan dibagi bersama. Jika terjadi kerugian maka BMT akan menarik kembali barang modal tadi; kecuali kalau kerugian tersebut terjadi karena kecerobohan atau kelalaian pihak pengusaha, BMT bisa menempuh tindakan lain. Pada prinsipnya pembiayaan yang dilakukan tidak membebani nasabah.

Ini menjadi salah satu kekuatan BMT karena kecenderungan masyarakat adalah menginginkan adanya kespraktisan dalam urusan keuangan baik untuk menyimpan atau meminjam uang dengan biaya yang murah.

\section{c. Variasi Produk}

Memang diakui bahwa variasi produk yang dimiliki BMT masih sangat terbatas dibanding bank umum yang banyak terdapat di perkotaan. Namun yang menjadi menarik disini adalah penawaran beberapa produk yang mendukung peningkatan kualitas dan kuantitas ibadah kepada Allah. Produk-produk simpanan seperti Simpanan Haji, Simpanan Umroh, Simpanan Akekah, Simpanan Walimah, dan Simpanan Qurban merupakan sarana pembelajaran yang baik bagi muslim untuk memulai sejak dini menyisihkan dana mereka demi menjalankan ibadah kepada Allah.

Simpanan Qurban misalnya, nasabah tidak dapat mengambil tabungannya sebelum masa Idul Adha tiba. Sebagai wujud pelayanan kepada nasabah, BMT juga memberikan pelayanan pengadaan hewan qurban tersebut dan mengantarkannya langsung kepada nasabahnya. Inilah kekuatan produk BMT dalam membangun keimanan umat dengan membimbing sikap disiplin dalam menyisihkan dana untuk qurban.

Disamping produk simpanan ada juga produk-produk pinjaman yang juga cukup banyak diminati oleh nasabah seperti pembiayaan mudharabah, pembiayaan musyarakah, pembiayaan murabahah, dan pembiayaan bai' bithaman ajil. Pembiayaan yang cukup menarik disini adalah pembiayaan murabahah dan bai'bithaman ajil yang cukup jarang ditawarkan oleh bankbank konvensional. Kedua pembiayaan ini pada prinsipnya berusaha membantu nasabah yang ingin membeli suatu barang, baik yang bergerak atau yang tidak bergerak. BMT bertindak sebagai mediator dengan membelikan terlebih dahulu barang tersebut dan diserahkan kepada nasabah. Selanjutnya nasabah boleh membayar seharga barang dengan menambah keuntungan bagi BMT. Disini nasabah mempunyai selang waktu untuk membayar barang tersebut tergantung kemampuan nasabah. Untuk pembiayaan murabahah maka pelunasannya sekaligus pada waktu yang akan datang. Sedangkan untuk pembiayaan bai'bithaman ajil pembayarannya dapat dicicil beberapa kali sesuai kemampuan nasabah dan kesepakatan bersama. Transaksi yang dilayani BMT tidak harus besar 
sehingga banyak nasabah yang tertarik untuk memanfaatkan kedua pembiayaan ini sebagai alternatif untuk memenuhi kebułuhannya.

Variasi produk inilah yang membuat BMT lebih dinamis dan kreatif dalam menjalankan usaha. Prospek yang baik ini merupakan modal BMT berkiprah didalam membangun ekonomi umat.

\section{Lokasi yang Strategis}

Lokasi pendirian sebuah BMT merupakan salah satu unsuryang mendapat perhatian khusus bagi para pendiri. Penentuan lokasi BMT akan mempengaruhi prospek usaha BMT secara jangka panjang. Secara logika sederhana, nasabah akan mencari BMT yang mudah dijangkau.

Berdasarkan penelitian (Adnan, 2000) diperoleh fakta bahwa biasanya BMT terletak dekat dengan pusat-pusat kegiatan masyarakat seperti pasar, masjid, pesantren, balai desa, dan lain-lain. Dalam persentase terlihat bahwa $70 \%$ BMT terletak dekat dengan pasar, $15 \%$ dekat dengan pemukiman penduduk, $9 \%$ dekat dengan masjid, $2 \%$ dekat dengan kawasan industri, dan $4 \%$ dekat dengan lokasi lainnya seperti kawasan pertokoan dan pesantren.

Hal ini menunjukkan bahwa salah satu lokasi strategis bagi BMT adalah pasar tradisional. Pengelola BMT membidik nasabah yang kebanyakan golongan pedagang kecil sampai pedagang menengah. Bagian pemasaran akan masuk ke pasar-pasar yang memberikan pelayanan langsung kepada nasabah. Bisa jadi para nasabah baik penyimpan maupun peminjam tidak mengetahui di mana lokasi BMT-nya. Hal ini terjadi karena mereka terbiasa dilayani di tempat usaha mereka masing-masing.

\section{Sektor Riil sebagai Alternatif Sumber Keuntungan}

Sektor riil menjadi primadona bagi pengembangan BMT. Berdasarkan fakta yang ada di Grobogan, Jawa Tengah yaitu BMT Ben Taqwa yang mempunyai usaha sektor riil dengan omset yang cukup tinggi. Salah satu usaha sektor BMT Ben Taqwa yang cukup menguntungkan adalah jual beli kendaraan bermotor. BMT ini memiliki beberapa toko jual beli kendaraan bermotor yang tersebar dibeberapa kecamatan di Grobogan.

Fenomena tersebut menunjukkan bahwa kemampuan BMT dalam memobilisasi dana pada sektor riil dapat memberikan kontribusi yang cukup besar bagi permodalan BMT. Ada dua dampak yang akan terjadi dengan adanya tambahan usaha sektor riil yaitu, pertama keuntungan BMT akan meningkat sehingga memungkinkan BMT meningkatkan kesejahteraan pengelola. Kedua, bagi hasil yang diberikan kepada nasabah akan meningkat seiring dengan peningkatan kuantitas usaha pada sektor riil. Hal ini tentunya menjadi salah satu kekuatan positif bagi BMT dalam meningkatkan gairah pengelola untuk menjaring nasabah sebanyak-banyaknya.

\section{Kepedulian Sosial yang Tinggi}

Kepedulian sosial ini sering kali diwujudkan dengan mengadakan kegiatankegiatan sosial berupa pengajian nasabah dan pengelola secára rutin sebulan sekali, membantu putra putri nasabah dalam beasiswa pendidikan, dan 
membantu fakir miskin untuk meningkatkan taraf hidupnya.

Fungsi ini dapat berjalan dengan baik karena dioptimalisasikannya Baitul Maal dengan baik. BMT menerima dana ZIS dari masyarakat dan menyalurkannya kepada yang membutuhkan. Salah satu pembiayaan BMT yang bersumber dari dana ZIS dan mempunyai fungsi sosial ekonomi yang tinggi adalah Al Qardhul Hasan. Al Qardhul Hasan adalah pembiayaan yang diberikan atas dasar kewajiban sosial semata. Pada pembiayaan ini, peminjam tidak dituntut untuk mengembalikan apapun kecuali modal pinjaman.

Pada dasarnya Al Qardhul Hasan merupakan pinjaman yang diberikan kepada mereka yang memeriukan pinjaman konsumtif jangka pendek untuk tujuan-tujuan yang sangat penting seperti biaya pengobatan, dana renovasi tempat tinggal akibat musibah tertentu, dan biaya lain yang mendesak. $\mathrm{Al}$ Qardhul Hasan juga diberikan kepada pengusaha (kecil) yang kekurangan dana tetapi mempunyai prospek usaha yang baik. Pada dataran inilah Al Qardhul mempunyai nilai sosial ekonomi yang tinggi. Menurut penelitian (Adnan, 2000), pembiayaan Al Qardhul Hasan menunjukkan kuantitas kegiatan yang cukup tinggi dari total pembiayaan yang dikeluarkan oleh BMT. $\mathrm{Hal}$ ini berarti BMT cukup konsisten dengan melaksanakan sistem pembiayaan ini, mengingat mereka memiliki tanggung jawab menyampaikan amanat dari masyarakat melalui alokasi dana ZIS. Penggunaan dana ZIS ini mengurangi beban BMT karena ada kemungkinan peminjam tidak dapat mengembalikan dana tersebut atau paling tidak modal pokok akan kembali.

Kepedulian sosial BMT melalui dana ZIS merupakan daya tarik tersendiri bagi nasabah untuk bergabung dengan BMT. Bagi nasabah penabung, selain mendapatkan keuntungan bagi hasil yang halal, mereka juga merasa senang bisa membantu orang lain yang membutuhkan dana.

\section{B. KELEMAHAN (WEAKNESS)}

1. Sumber Daya Manusia

BMT merupakan organisasi yang berbasis manajemen sehingga kemampuan dan keterampilan sumber daya menusia sangat mempengaruhi perkembangan BMT. Pengurus BMT terkadang kurang memperhatikan aspek peningkatan kualitas sumber daya manusia, apalagi BMT yang tidak memiliki "induk semang" atau berdiri sendiri tanpa bimbingan lembaga lain seperti PINBUK, BMT Center, atau Muamalat Center Indonesia.

Rata-rata, manajemen BMT masih dikelola oleh SDM dengan level rendah setaraf SLTAdan hanya sebagian kecil berpendidikan Strata-1 (S1). Masalah ini tentunya terkait juga dengan pendapatan yang mereka terima dari BMT. Memang pada awal-awal berdiri BMT belum dapat menjanjikan penghasilan yang lumayan. Bagi kebanyakan lulusan S1, bekerja di BMT bukan merupakan pilihan utama karena mereka menganggap bahwa penghasilan yang diterima tidak sesuai dengan harapan. Hanya orang-orang yang kuat komitmen keagamaan saja yang mau bergabung bersama BMT. Harus diakui bahwa beban pekerjaan yang ada di BMT cukup berat apalagi pada awal-awal pertumbuhan.

\section{Permodalan yang Terbatas}


BMT biasanya didirikan dengan modal yang terbatas, paling tidak BMT bisa membeli peralatan kantor dan menutup biaya-biaya operasional bulanbulan awal. Mestinya BMT masih memerlukan tambahan modal untuk pengembangan usaha selanjutnya. Padahal pemodal yang berinvestasi di BMT biasanya cenderung bermotif sosial keagamaan sehingga modal yang disalurkannya pun tidak begitu besar.

Berdasarkan data PINBUK, saat ini tercatat sebanyak 3.037 BMT di seluruh Indonesia dengan berbagai kondisi dan tingkat perkembangan, 85 persen di antaranya memiliki asset di bawah Rp 1 miliar. Sekitar 300 BMT beraset antara Rp 1-5 miliar, 150 BMT memiliki aset antara Rp 5-15 miliar dan baru 10 BMT saja yang berhasil menembus aset di atas Rp 15 miliar.

Di sisi lain, status BMT adalah sebuah koperasi atau Kelompok Swadaya Masyarakat yang independen sehingga BMT tidak memiliki basis permodalan yang kuat. Tidak seperti bank-bank umum atau BPRS yang berada dibawah naungan Bank Indonesia, mereka mendapat jaminan likuiditas permodalan. Hal ini sangat berdampak kepada daya saing di mata nasabah. Calon nasabah biasanya lebih percaya kepada bank-bank umum yang dananya dijamin Bank Indonesia daripada kepada BMT yang belum jelas latar belakang permodalannya. Keterbatasan modal ini juga dapat menghambat proses pemberian pembiayaan bagi nasabah perninjam. Akhirnya nama BMT-lahyang dipertaruhkan di mata nasabahnya.

\section{Kurangnya Sosialisasi BMT}

Perlu disadari bersama bahwa sosialisasi BMT sangat kurang, sehingga masyarakat sering mempunyai persepsi yang keliru mengenai BMT. Ada sebagian masyarakat dengan ekstrem mensejajarkan BMT sama dengan posisi "rentenir-rentenir" yang banyak beroperasi di pasar. Hal inilah yang menjadi kendala bagi BMT untuk dapat berkembang dengan baik. Pengelola memang perlu bekerja keras dalam menjelaskan BMT kepada para calon nasabahnya karena sebagian besar masyarakat masih awam dengan sistem bagi hasil.

Kurangnya sosialisasi ini juga berdampak kepada kepercayaan masyarakat terhadap BMT. Mereka cenderung berpaling dari BMT yang dianggap lembaga keuangan kecil yang tidak meyakinkan keberadaannya. Hal ini sering dialami khususnya bagi BMT-BMT yang berada di kawasan perkotaan yang sudah dipenuhi dengan lembaga-lembaga keuangan konvensional berbasis bunga.

\section{Kurangnya Komunikasi antar BMT}

Komunikasi antar lembaga-lembaga keuangan sejenis merupakan sebuah kekuatan bagi pengembangan organisasi. Hal inilah yang kiranya kurang diperhatikan oleh BMT-BMT yang berdiri secara independen. Para pengelola dan pengurus kurang menyadari manfaat adanya komunikasi|yang kontinyu dengan BMT-BMT lain. Padahal dengan adanya komunikasi antar BMT dalam satu wilayah yang sama justru akan mẹmperkuat ikatan di antara mereka. Langkah ini akan mengurangi iklim persaingan yang tidak sehat diantara mereka. Sangat disayangkan apabila antar BMT justru bersaing secara tidak sehat dalam menarik nasabahnya. 
Dengan komunikasi yang kontinyu mereka bisa berbagi pengalaman masing-masing dan saling membantu dalam permodalan walau sebatas pinjam-meminjam modal untuk pembiayaan. Masalah ini biasanya dialami oleh BMT-BMT independen yang tidak memiliki lembaga fesilitator. Kedua lembaga ini pun terkadang juga kurang proaktif dalam mengajak BMT untuk saling berkomunikasi dengan mengadakan pertemuan-pertemuan dalam rangka menjalin persaudaraan antar BMT. Akhirnya inisiatif terpulang kepada masing-masing BMT.

\section{Kesulitan dalam Penerapan Sistem Profit Sharing}

Sistem bagi hasil pada dasarnya menghendaki adanya keadilan. Namun hal ini memberikan masalah baru karena penerapan sistem ini tidak semudah yang dibayangkan. Akad perjanjian bagi hasil menimbulkan perhitungan yang lebih rumit dibandingkan sistem bunga karena standar yang digunakan juga tidak sama. Hal ini sangat dirasakan oleh BMT-BMT yang berlokasi dekat dengan pasar tradisional dan memiliki nasabah sebagian besar pedagangpedagang kecil.

Para pedagang tersebut masih asing dengan adanya sistem bagi hasil. Pada prinsipnya bagi nasabah peminjam cenderung menginginkan modal dengan cepat tanpa prosedur yang berbelit-belit. Mereka juga tidak pernah mengadakan pembukuan sehingga sangat sulit memperhitungkan untung dan rugi yang diperoleh sehari-hari. Akhirnya pengelola BMT perlu dengan sabar menjelaskan mekanisme pembiayaan. Untuk mengurangi kesulitan tersebut terkadang BMT akhirnya mengambil keputusan dengan menetapkan keuntungan pedagang secara rata-rata. Hal ini bisa menjadi masalah ketika perhitungan untung rugi tidak digunakan lagi karena mereka kembali pada perhitungan dengan rata-rata tetap. Samakah ini dengan bunga? Ini menjadi titik kritis yang perlu mendapat perhatian kita bersama.

\section{Kesulitan Analisa Pembiayaan dan Kontrol terhadap Pembiayaan}

BMT mempunyai kendala dalam melakukan analisa proyek (project feasibility) untuk proyek pembiayaan karena belum ada standar baku untuk menilai kemampuan pengembalian modal sebuah proyek (Kurnila, 1999). Hal ini erat kaitannya juga dengan kualitas SDM yang menangani masalah pembiayaan.

Disamping itu BMT juga mengalami kesulitan mendapat informasi tentang kekuatan sebuah proyek atau rencana usaha karena biasanya nasabah tidak mau berbelit-belit dalam meminjam dana. Survey sederhana dengan meninjau lokasi sudah merupakan analisa yang dirasakan cukup untuk memutuskan sebuah pembiayaan. Kalau rencana usaha ini berskala kecil tidak menjadi masalah. Bagaimana kalau menyangkut rencana usaha dengan jumlah modal besar?

Pengelola juga merasa kesulitan dalam mengontrol penggunaan dana pembiayaan yang diberikan kepada nasabah karena sebagian besar mereka tertutup dalam masalah keuangan dan hampir tidak pernah ada catatan keuangan. Keadaàn ini bisa diperparah dengan adanya kredit macet dari nasabah. Tanpa adanya catatan keuangan yang jelas dari nasabah peminjam 
maka BMT kesulitan untuk menentukan penyebab kemacetan pengembalian pembiayaan tersebut.

Terkadang nasabah melakukan tindakan yang nakal yaitu dengan sengaja tidak mau melunasi kewajibannya. Nasabah menggunakan kelemahan BMT yang punya sifat selalu berprasangka baik pada orang lain sehingga BMT kewalahan menghadapi kondisi semacam itu.

\section{PELUANG (OPPORTUNITY)}

Kelemahan yang melekat pada diri BMT tidak berarti bahwa BMT tidak bisa berkembang lebih baik lagi. Masih banyak peluang yang dimiliki BMT untuk mengembangkan diri menjadi lembaga keuangan mikro yang bisa menjadi andalan masyarakat.

Pertama, salah satu kunci keberhasilan BMT adalah bagaimana bisa meraih kepercayaan dari masyarakat dan mengenali nasabah secara intens dan cepat. Hal ini dimungkinkan karena transaksi dilakukan secara harian. Selain itu ada keseimbangan antara jumlah nasabah penabung dan yang membutuhkan pembiayaan. BMT juga memberikan pendampingan UMKM setelah memberikan kredit yang ternyata sangat efektif mengendalikan tingkat kemacetan, disamping meningkatkan kinerja dan kesejahteraan usaha kecil. Tidak mengherankan kalau pembiayaan yang bermasalah dalam lembaga ini relatif sangat kecil, kurang dari $2 \%$.

Peran BMT menjadi penting justru pada saat perekonomian sedang mengalami krisis. Ketika bank ramai-ramai menaikan suku bunganya, BMT justru menjadi alternatif pembiayaan bagi pengusaha mikro. Kemudahan prosedur dan jangkauan layanan selama ini menjadi kelebihan BMT dibandingkan dengan lembaga-lembaga keuangan besar. Dan selama 10 tahun terakhir ini, BMT terbukti mampu memberdayakan sedikitnya 1,5 juta pengusaha kecil dengan total asset mencapai sekitar Rp 1,5 trilyun rupiah (Republika, 2005). Saat ini, kalangan pengusaha mikro dan kecil yang sebelumnya mengandalkan kredit bank mulai berpaling ke lembaga jasa pembiayaan syariah, termasuk BMT. Hal ini dipicu oleh persyaratan pinjaman yang fleksibel dan sistem bagi hasil 'sesuai syariah.

Kedua, adanya peluang pembiayaan dari sektor koperasi syariah yang akan terus meningkat menyusul akan segera diakuinya spesifikasi standarisasi lembaga koperasi syariah oleh pemerintah.

Ketiga, data Kementerian Negara Koperasi tahun 2004 menyebutkan bahwa dari 42,452 juta entitas usaha, 41,8 juta atau $98,5 \%$ merupakan usaha mikro, 650 ribu merupakan usaha kecil dan menengah, serta 2 ribu lainnya adalah usaha besar. Meskipun jumlah usaha mikro dan UKM sangat banyak, baru sekitar $30 \%$ yang tersentuh perbankan atau lembaga keuangan non bank, sehingga BMT mempunyai peluang untuk meningkatkan pembiayaan dengan memperluas jaringan melalui pembukaan cabang. Ekspansi masih terbuka lebar tidak hanya untuk UKM saja melainkan sektor usaha menengah lainnya.

\section{ANCAMAN (THREATEN)}

Keberhasilan suatu lembaga dalam menjalankan kegiatánnya pasti memunculkan pesaing yang ingin ikut menikmati hasil yang mengüntungkan. Demikian juga dengan keberhasilan BMT dalam menjadikan dirinya sebagai pilihan 
bagi pengusaha kecil untuk mengembangkan usaha. Perkembangan BMT yang semakin pesat, rupanya dilihat secara jeli oleh perbankan nasional yang sekarang dikuasai oleh investor asing. Mereka mulai melirik ceruk pasar yang digarap BMT dengan kekuatan teknologi dan modal yang besar, bahkan mereka melakukan rekruitmen terhadap SDM-SDM BMT yang ada untuk bersaing dengan lembaga yang dulu ditekuninya, sesuatu yang lazim namun ironi.

\section{ALTERNATIF SOLUSI}

Setelah memperhatikan berbagai kendala dan tantangan yang dihadapi BMT dalam kegiatannya, maka pada bagian ini penulis mencoba merumuskan alternatif solusi. Solusi yang ditawarkan tentunya tidak sepenuhnya dapat menyelesaikan semua kendala yang dihadapi. Namun paling tidak solusi yang ditawarkan nantinya bisa membuka wacana baru bagi pengembangan BMT di kemudian hari.

Pertama, kualitas SDM yang terbatas dapat diatasi dengan memberikan pelatihan-pelatihan bagi karyawan-karyawan BMT secara berkala dan berkesinambungan. Hal ini perlu menjadi prioritas pengembangan usaha BMT itu sendiri. BMT itu tidak bisa hanya tinggal diam menerima kenyataan rendahnya kualitas SDM. Perlu adanya perencanaan dalam mengalokasikan sebagian keuntungan BMT untuk memberikan pendidikan tambahan bagi karyawan. Mereka bisa mendatangkan dosen-dosen atau praktisi yang mempunyai wawasan keilmuan dan pengalaman yang luas.

Langkah alternatif lain yang bisa diambil adalah dengan mengembangkan relasi yang luas terutama dengan lembaga-lembaga keuangan syariah lain. Diharapkan dengan hubungan yang baik diantaranya, mereka bisa saling bertukar pikiran dan pengalaman. Hal ini juga merupakan sebuah proses pembelajaran yang cukup efektif. Antara BMT dan lembaga keuangan syariah lain bisa mengadakan diskusi rutin dengan membahas berbagai tema aktual berkaitan dengan perbankan syariah sehingga mereka tidak ketinggalan berita.

PINBUK dan lembaga fasilitator lain sebagai lembaga yang menaungi BMT-BMT diharapkan semakin berpartisipasi aktif dalam menyelesaikan permasalahan BMT agar lembaga-lembaga tersebut tidak terlihat seolaholah hanya dibutuhkan pada saat BMT kekurangan modal usaha. Langkah evaluasi dan supervisi secara kontinyu perlu menjadi target bisa tercapai. Langkah ini perlu segera direalisasikan karena adanya tuntutan profesionalisme dalam pengelolaan BMT.

Kedua, permodalan BMT yang terbatas sebenarnya bisa diatasi dengan optimalisasi dana ZIS. BMT perlu mengambil inisiatif yang bijaksana dalam mengelola dana ZIS sebaik mungkin dan bertanggung jawab mengingat ZIS merupakan amanah orang banyak. Tetapi terkadang justru BMT khawatir bahwa penggunaan dana ZIS untuk modal usaha BMT tidak sesuai dengan syariat islam. Tidak ada salahnya menggunakan dana ZIS karena memang tujuan kegiatan BMT adalah membangkitkan perekonomian umat dan membantu golongan ekonomi lemah. Ini merupakan salah satu ikhtiar umat yang positif.

Alternatif lain yang dapat ditempuh yaitu dengan mengadakan kerjasamakerjasama dengan lembaga keuangan syariah lain atau BMT lain untuk saling 
membantu masalah permodalan. Misalnya, antar BMT bisa saling pinjam meminjam dana untuk pembiayaan atau sekedar sebagai cadangan dana untuk memenuhi permintaan nasabah penyimpan yang akan menarik dananya.

Dalam hal ini pemerintah perlu memberikan perhatian khusus dengan membentuk sebuah lembaga likuiditas yang secara khusus menjamin permodalan BMT. Pemerintah bisa melakukannya melalui Bank Indonesia secara bertahap. Dengan adanya lembaga likuiditas tersebut, diharapkan BMT akan mempunyai daya tarik tersendiri tehadap nasabahnya yang pada akhirnya akan turut mendorong peningkatan kredibilitas BMT di mata masyarakat.

Ketiga, konsep pemasaran yang agresif perlu diterapkan oleh setiap BMT. $\mathrm{Hal}$ ini perlu menjadi prioritas yang patut diperhitungkan oleh BMT karena perkembangan jumlah nasabah sangat tergantung dengan efektifitas sistem pemasaran yang dijalankan.

Konsep pemasaran tidak harus membutuhkan dana yang besar. Pihak BMT perlu mengadakan pendekatan dengan tokoh-tokoh masyarakat sekitar agar mereka mau ikut menyebarluaskan keberadaan BMT dan keuntungan yang diperoleh oleh masyarakat bila bergabung dengan BMT.Arena pengajian-pengajian dan majelis-majelis ta'lim yang ada disekitar BMT perlu "dikuasai, karena banyak calon nasabah potensial yang ikut dalam majelis tersebut. Pemuka-pemuka agama perlu diajak bersama-sama membangun BMT sehingga lingkungan sekitar akan merasa ikut memiliki BMT tersebut. Hal itu tidak membutuhikan biaya yang besar karena semuanya tergantung dari komitmen pengurus dan pengelola BMT untuk berupaya keras mengembangkan usahanya.

Keempat, prinsip bagi hasil perlu mendapat perhatian yang serius dari semua pihak karena hal ini menyangkut nilai ibadah yang dijalankan. Kalau BMT merasa kesulitan dalam penerapan bagi hasil maka perlu membangun sebuah sistem bagi hasil yang sederhana dan tidak menimbulkan keraguan. Berdasar (Antonio, 2001), paling tidak ada 5 (lima) prinsip pokok yang harus diperhatikan dalam sistem bagi hasil:

a. Penentuan besarnya rasio/nisbah bagi hasil dibuat pada waktu akad dengan berpedoman pada kemungkinan untung rugi.

b. Besarnya rasio bagi hasil berdasarkan pada jumlah keuntungan yang diperoleh.

c. Bagi hasil bergantung pada keuntungan proyek yang dijalankan. Bila usaha merugi, kerugian akan ditanggung bersama oleh kedua belah pihak.

d. Jumlah pembagian laba meningkat sesuai dengan peningkatan jumlah pendapatan.

e. Tidak ada yang meragukan keabsahan bagi hasil.

Ketentuan ini sekilas memang mengandung sebuah potensi risiko yang cukup besar bagi BMT mengingat kerugian yang timbul akan ditanggung kedua belah pihak. Inilah yang sering kali dijadikan alasan bagi BMT untuk melalaikan pelaksanaan bagi hasil secara murni. Padahal inti dari pelaksanaan sistem perbankan syariah adalah profit and loss sharing. Kalau BMT tetap merasa ketakutan dengan kerugian yang diperoleh maka sebaiknya perlu adanya kiat khusus untuk mengambil langkah preventif dalam menentukan proyek yang akan dibiayai.

Langkah preventif yang perlu diambil sangat berkaitan erat dengan masalah lemahnya analisa proyek dan kontrol yang dilakukan oleh BMT. Kenyataannya memang mental sebagian pengusaha kita masih perlu dipertanyakan khususnya 
menyangkut masalah kejujuran. Nilai kejujuran ini merupakan salah satu kunci pokok keberhasilan penerapan sistem bagi hasil. Kalau kedua belah saling tidak percaya dan tidak saling terbuka maka sebaiknya jangan dilakukan akad pembiayaan. Berkaitan dengan hal tersebut BMT perlu mengambil langkahlangkah prenventif dalam memberikan pembiayaan terhadap proyek, khususnya yang membutuhkan alokasi dana yang cukup besar, antara lain :

a. Mengadakan analisa kelayakan proyek yang diajukan oleh nasabah dengan paling tidak mensyaratkan adanya permohonan tertulis dari peminjam, dengan dilampiri proposal yang memuat gambaran umum usaha, rencana atu prospek usaha, rincian penggunaan dana, jumlah kebutuhan dana, dan omset yang yang diperoleh setiap bulannya.

b. Legalitas usaha milik peminjam perlu diketahui secara pasti seperti akta pendirian usaha, surat izin umum perusahaan, dan tanda daftar perusahaan.

c. Laporan keuangan seperti neraca, laporan rugi laba, dan laporan arus kas perlu diketahui secara pasti oleh BMT.

d. Melakukan kontrol yang ketat terhadap pembiayaan yang diberikan dengan memperjanjikan adanya keleluasaan bagi BMT untuk setiap saat melihat perkembangan proyek yang dibiayai terhadap peminjam.

e. BMT perlu menerapkan sistem pembiayaan bertahap, artinya dana pinjaman yang dikucurkan tidak diberikan sekaligus, namun dipecah menjadi beberapa bagian dengan rentang waktu yang sesuai dengan kebutuhan peminjam.

Kalau dilihat sekilas memang akhirnya akan memberatkan peminjam dalam memenuhi kewajibannya. Namun hal ini merupakan antisipasi paling aman bagi BMT dalam memberikan pembiayaan proyek. Ketentuan ini tidak dapat diterapkan kepada semua nasabah mengingat nasabah peminjam BMT justru rata-rata golongan ekonomi lemah. Ketentuan ini diterapkan tentunya bagi pengusaha menengah ke atas yang mengajukan peminjaman dana dalam jumlah besar.

Bagi golonagan ekonomi lemah perlu dibantu dengan meringankan prosedur dan BMT bisa saja akhirnya menggunakan dana ZIS seperti penjelasan pada bagian sebelumnya.

\section{A. Kesimpulan}

Dari pembahasan masalah prospek serta tantangan yang dihadapi BMT, maka pada akhir tulisan ini akan ditarik beberapa kesimpulan antara lain :

a. BMT merupakan sebuah fenomena yang unik dalam perkembangan sistem ekonomi syariah di Indonesia dimana keberhasilan BMT dalam membangun usaha dengan berbagai tantangan yang menghadang ternyata dipengaruhi oleh faktor besarnya komitmen pengurus dan pengelola BMT dalam menegakkan syariat Islam yang diimplemantasikan dengan memberikan pelayanan yang baik kepada nasabah, memberikan prosedur yang ringan, menawarkan produk yang variatif, menumbuhkan kepedulian sosial terhadap masyarakat, memberikan bagi hasil yang menguntungkan bagi nasabah dengan usaha meningkatkan kegiatan di sektor riil.

b. Dibalik keberhasilan BMT tentunya diikuti dengan munculnya berbagai masalah dan tantangan yang dihadapi oleh BMT antara lain masih lemahnya kualitas SDM, permodalan yang terbatas, kurangnya komunikasi antar BMT, kesulitan 
dalam penerapan sistem bagi hasil, dan lemahnya analisa pembiayaan dan kontrol terhadap suatu proyek.

c. Kita semua perlu mengakui bahwa keberadaan BMT telah memberikan warna baru bagi perekonomian bangsa kita secara umum dan sistem ekonomi syariah secara khusus dengan melihat fakta cukup besarnya kontribusi BMT dalam mendorong perekonomian umat.

B. Penutup

Akhirnya perlu adanya kesadaran dari semua pihak termasuk pemerintah, tokoh-tokoh masyarakat, pemuka-pemuka agama kita, serta seluruh elemen masyarakat bahwa Bangsa Indonesia yang mayoritas muslim iniperlu bersamasama mendorong kemajuan BMT sebagai salah satu pondasi sistem ekonomi syariah di Indonesia. 


\section{DAFTAR PUSTAKA}

Antonio, Muhammad Syafi'i. 2001. BANK SYARIAH: Dari TeoriKe Praktik. Jakarta : Gema Insani Press dan Tazkia Cendekia.

Adnan, Muhammad Akhyar. 1999. Prospek Lembaga Keuangan Islam. Paper yang dipresentasikan di Universitas Muhammadiyah Yogyakarta.

,dkk. 2000. Study on Factors Influencing Performance of the Best Baitul Maal wat Tamwils (BMTs) In Indonesia. Unpublished Research. Pusat Pengkajian dan Pengembangan Ekonomi Islam (P3EI), Fakultas Ekonomi, Universitas Islam Indonesia.

Dumairy. 1999. Lembaga Keuangan Islam : Problem, Tantangan, dan Peluang Di Era Reformasi. Jurnal Ekonomi Studi Pembangunan UMY, Vol $1 /=$ 2000.

Kurnila, Indrana Meini. 1999. Manajemen Produk Pembiayaan Dalarn Mengantisipasi Pembiayaan Bermasalah Pada BMT Al-Ikhlas. Paper pada Sekolah Tinggi limu Syariah, Yogyakarta. Mikro

Republika. 2005. 10 Tahun, BMTMampu Berdayakan 1,5Juta Pengusaha

Republika. 2005. BPRS Perlu Tabungan Bersama

PINBUK. 1999. Pedoman Cara Pembentukan BMT. Jakarta : PINBUK Press.

: PINBUK Press.

1999. Peraturan Dasar dan ContohAnggaran Dasar BMT. Jakarta

1999. Kajian Evaluasi Pengembangan Koperasi Pondok Pesantren dan BMT. Paper Bersama Kerjasama PINBUK dan Proyek Pengembangan dan Pemantapan Koperasi Perkotaan, Dirjen Koperasi Perkotaan, Departemen Koperasi dan Pengusaha Kecil Republik Indonesia.

Surat Keputusan Direksi Bank Indonesia tentang BPR Syariah No. 32/36/ . KEP/DIR tanggal 12 Mei 1999

Undang-Undang Perseroan Terbatas No. 1 tahun 1995

Undang-Undang Perbankan No. 7 tahun 1992

Undang-Undang Perbankan No. 10 tahun 1998 